ZOOLOGIA 27 (3): 353-362, June, 2010

doi: $10.1590 /$ S1984-46702010000300006

\title{
Seasonal variation of ground spiders in a Brazilian Savanna
}

\section{Marina Farcic Mineo'; Kleber Del-Claro', ${ }^{1}$ \& Antonio Domingos Brescovit ${ }^{2}$}

\author{
${ }^{1}$ Instituto de Biologia, Universidade Federal de Uberlândia. Campus Umuarama, Rua Ceará s/n, 38400-902 Uberlândia, \\ Minas Gerais, Brasil. \\ ${ }^{2}$ Laboratório de Artrópodes Peçonhentos, Instituto Butantan. Avenida Vital Brasil 1500, 05503-900 São Paulo, São Paulo, Brazil. \\ ${ }^{3}$ Corresponding author. E-mail: delclaro@ufu.br
}

\begin{abstract}
The Brazilian Savanna Ecoregion (Cerrado) is one of the richest biomes in the world, with a characteristic highly seasonal climate a dry season between May and September and a rainy season from October through April. Ground-dwelling spiders from three Cerrado phytophysiognomies, "campo cerrado", "cerrado" and "cerradão", were sampled using pitfall traps during two years, totaling 111 species and 3,529 individuals. The abundance of individuals and species richness was higher during the wet season. Fifty-eight species were captured exclusively during that period, whereas only nineteen were restricted to the dry season. Only two species were found in all samples. The number of juveniles was higher than the number of adults in all phytophysiognomies and in all species during both seasons. The highest abundance was registered in October and the lowest in April. Overall sex ratio was male-biased in all vegetation types sampled. Distinct climate variables affected the abundance of spiders depending on sex, age and vegetal physiognomy where they were sampled. This study involved the longest sampling of spider abundance and diversity on the ground of a Brazilian Savanna.
\end{abstract}

KEY WORDS. Araneae; Brazil; community ecology; seasonality.

Seasonality (WOLDA 1988) is an important factor to consider in studies that discuss species richness and abundance. Despite its relevance, however, seasonal variations have received little attention from Tropical environmentalists until recently (e.g. Rosenzweig 1995). Although seasonal changes in temperature tend to be minimal or absent in the Tropics, it is not accurate to say that there are no seasons (Wolda 1988). In fact, rainy seasons alternate with one or two dry seasons each year.

Seasonal changes in flora and fauna are determined by abiotic conditions including weather variables. Animals, due to behavioral and physiological characteristics, react differently to the influence of abiotic factors. Some studies have demonstrated that seasonality influences the abundance, growth rate, and size of spiders (GASTON et al. 1993, GASNIER et al. 2002). Environmental characteristics also have a strong influence on spider habitat selection (Uетz 1992).

Spiders play an important role in many terrestrial ecosystems due to their predatory nature, abundance, and ubiquity. Because they are at the top of the invertebrate trophic chain these arachnids can regulate decomposer populations (WISE 1993).

Little is known about the influence of seasonality on the araneofauna of Savanna regions, even though a few well-documented studies have been conducted in some African countries (e.g. Russel-Smith 2002, Whitmore et al. 2002, Modiba et al. 2005). Despite the fact that Brazilian Savannas (Cerrado Biome) are quite diverse - in species and micro-habitats, see OliverRa \& Marquis (2002) and GotTsberger \& Silbebauer-Gottsberger (2006) - , occupying $25 \%$ of the Brazilian territory, studies on spiders are rare and restricted to a single phytophysiognomy or guild (e.g. RINALDI \& ForTI 1996).

This study tested the hypothesis that the seasonal variation in temperature and humidity observed in a Brazilian savanna promotes a strong seasonal pattern in the species composition and abundance of ground spiders.

\section{MATERIAL AND METHODS}

The present study was carried out at the Panga Ecological Station, an area of 404 hectares, located $30 \mathrm{Km}$ south of the city of Uberlândia $\left(19^{\circ} 11^{\prime} 10^{\prime \prime} \mathrm{S}, 48^{\circ} 23^{\prime} 30^{\prime \prime} \mathrm{W}\right)$, state of Minas Gerais, southeastern Brazil (Fig. 1). The region, located $800 \mathrm{~m}$ above sea level, is characterized by a highly seasonal climate, with dry winters (from April through September) and rainy summers (from October through March). The average annual precipitation is $1500 \mathrm{~mm}$. Local temperature and precipitation were recorded during the two years of the study (Fig. 2).

Three different Savanna formations (phytophysiognomies), namely campo cerrado, cerrado and cerradão, were sampled. The campo cerrado is characterized by grasslands with scattered shrubs and small trees. The cerrado vegetation is predominantly arboreal-shrub with an herbaceous stratum, 20- 


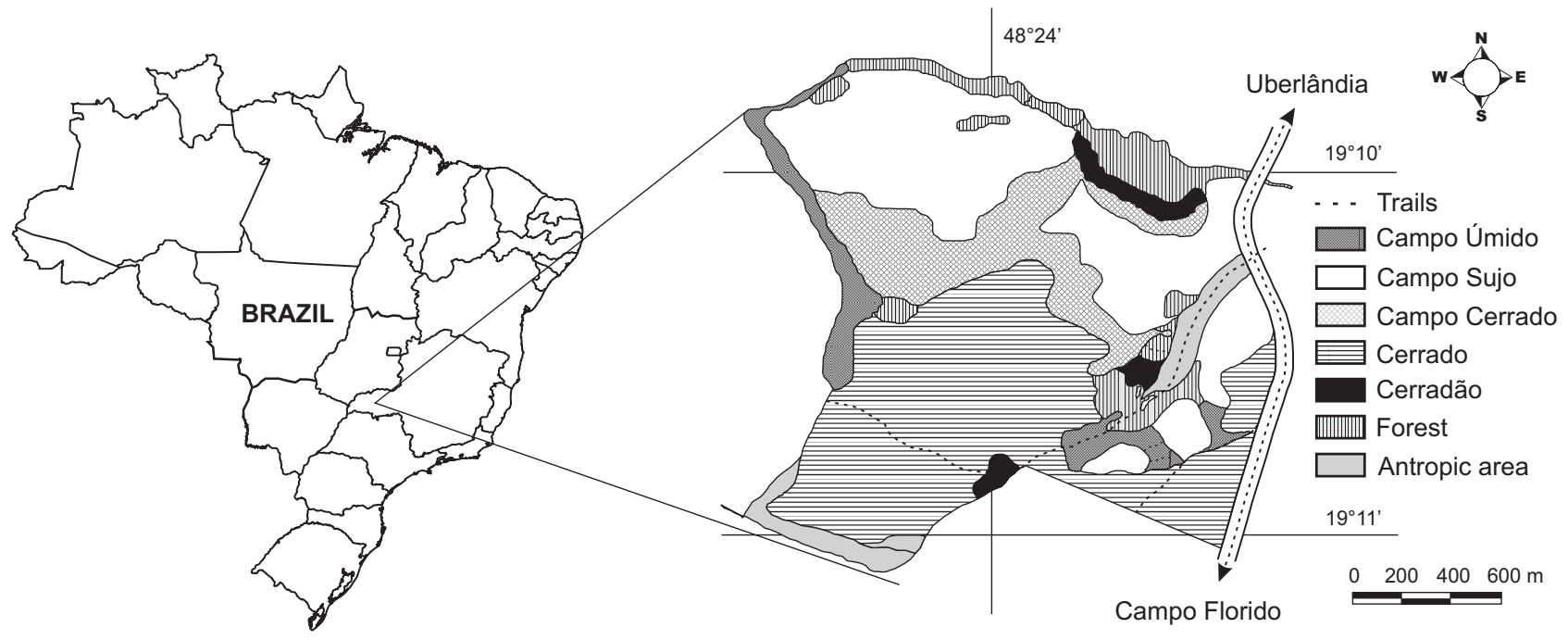

Figure 1. Location of the Panga Ecological Station, an area of preserved Brazilian Savanna. Adapted from SCHIAVINI \& ARAUjo (1992).

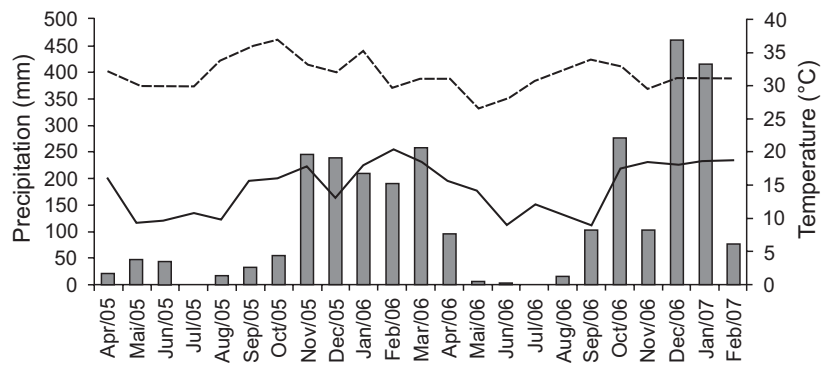

Figure 2. Climate data from the Panga Ecological Station, Minas Gerais, Brazil. (-) Minimum temperature, (--) maximum temperature and (bars) precipitation.

$50 \%$ tree cover and average tree height of three to six meters. The cerradão is an almost closed woodland with a $50 \%$ to $90 \%$ crown tree cover (trees are often three to eight meters, or taller), casting considerable shade that reduces surface exposure (Oliveira-Filho \& RatTer 2002).

Ground spiders were collected using pitfall traps. Each trap consisted of a plastic jar $7 \mathrm{~cm}$ in diameter and $10 \mathrm{~cm}$ long. Traps were inserted into the ground and were half filled with a mixture of $70 \%$ ethanol and glycerol. In each phytophysiognomy, an area of 2,592 $\mathrm{m}^{2}$ was divided into 12 quadrants of $12 \times 18 \mathrm{~m}$ each. One quadrant in each habitat type was sampled every two months. Traps were aligned in five rows, each containing eight traps, with a distance of two meters between rows and between traps. Traps were left in the field for five consecutive days. Each quadrant was sampled only once. The total trapping effort involved 2,400 traps for each site, sampled between April, 2005 and February, 2007.
Adults were sexed and identified to the lowest taxonomic level possible. All specimens were identified at least to family. For the analyses, BioEstat 5.0 was used (Ayres et al. 2007). Spider abundances were used in stepwise multiple regressions against the following local environmental variables: maximum, minimum and medium temperature, relative humidity, total precipitation and maximum precipitation during 24 hours. Because we wanted to investigate whether climatic variables affect the araneofauna and, if so, to ascertain whether the effect of these variables is immediate or delayed, we analyzed data pertaining to the sampling month as well as data from one and two months prior to sampling. Voucher specimens were deposited in the Arachnida and Myriapoda Collection of the Instituto Butantan, São Paulo, Brazil (Curator: A.D. Brescovit).

\section{RESULTS}

The species composition of the ground-dwelling spiders, as well as their distribution over the two years of the study, varied according to habitat type and season. A total of 111 species, 31 families and 3,529 individuals were collected (Appendix 1). Most spiders were collected during the wet season ( $\mathrm{N}=2,578$ individuals and 90 species). In the dry season, 951 individuals and 51 species were captured. Of the species sampled, 58 were restricted to the wet season, whereas 19 were found exclusively during the dry season. Several families $(\mathrm{N}=11,35 \%)$ and many species $(\mathrm{N}=$ $67,60 \%)$ were represented by less than three individuals. Only two species were sampled throughout the 12 periods of collection: Apopyllus silvestrii (Simon, 1905) $(\mathrm{N}=73)$, and Hahniidae sp. $1(\mathrm{~N}=76)$. Twenty-nine percent of the specimens were captured in the campo cerrado, $37 \%$ in the cerrado and $34 \%$ in the cerradão.

Climate variables affected spider abundance differently, 
depending on the sex and age of the spiders and the phytophysiognomy of the sampling site (Tab. I). Total spider abundance was affected primarily by relative humidity two months before sampling. Additionally, in the Cerradão, climatic changes in the sampling month also influenced the spiders. Richness and abundance of males were affected by different climate variables depending on habitat type, for example, abundance of females from the three habitat types were influenced mainly by maximum temperature and maximum precipitation in a period of $24 \mathrm{~h}$ during the sampling month. Juveniles in the Cerrado and Cerradão were affected by distinct climatic factors: temperature, humidity and precipitation, starting two months before sampling. Juvenile abundance and richness in the Campo cerrado, and male abundance in the Cerradão were not affected by any of the climate variables measured.

The number of juveniles was higher than that of adults in all habitat types and seasons, with the exception of the wet season in the Cerrado and Cerradão. During the two years of our study, the highest number of males was observed in October ( $\mathrm{N}$ $=1,131$ ), except for the Campo Cerrado, where the abundance of males during the first year was higher in December (Figs 3-6).

Abundance of females did not change significantly during the two years. During the first year, the lowest abundance of juveniles was recorded in October and, over the second year,

Table I. Significant relationships between ground spiders of three phytophysiognomies of the Brazilian savanna and climate variables (maximum, medium and minimum temperature, relative humidity, total precipitation and maximum precipitation in a period of 24 hours) collected one and two months before, and during the sampling month, through multiple linear regression stepwise.

\begin{tabular}{|c|c|c|c|c|c|}
\hline Habitat type & Group & $\mathrm{R}$ & $\mathrm{F}$ & $\mathrm{p}$ & Climate variable (s) \\
\hline \multirow[t]{6}{*}{ Campo cerrado } & Total abundance & 0.8170 & 9.0367 & 0.0073 & two months before: relative humidity + total prec. \\
\hline & Richness & 0.5891 & 5.3156 & 0.0421 & current month: max. prec. in $24 \mathrm{~h}$ \\
\hline & & 0.5902 & 5.3462 & 0.0416 & two months before: max. temp. \\
\hline & Males & 0.8622 & 7.7220 & 0.0099 & $\begin{array}{l}\text { two months before: relative humidity }+ \text { min. temp. }+ \text { max. prec. } \\
\text { in } 24 \mathrm{~h}\end{array}$ \\
\hline & Females & 0.6692 & 8.1125 & 0.0167 & current month: max. prec. in $24 \mathrm{~h}$ \\
\hline & Juveniles & - & - & - & ns \\
\hline \multirow[t]{10}{*}{ Cerrado } & Total abundance & 0.7611 & 13.7675 & 0.0043 & two months before: relative humidity \\
\hline & & 0.8035 & 8.1993 & 0.0096 & two months before: relative humidity + min. temp. \\
\hline & Richness & - & - & - & ns \\
\hline & Males & 0.7432 & 5.5512 & 0.0266 & current month: max. temp. + max. prec. in $24 \mathrm{~h}$ \\
\hline & & 0.7294 & 5.1172 & 0.0324 & one month before: max. temp. + relative humidity \\
\hline & & 0.7049 & 4.4454 & 0.0448 & two months before: $\min$. temp + relative humidity \\
\hline & Females & 0.7875 & 7.3476 & 0.0129 & current month: max. temp. + max. prec. in $24 \mathrm{~h}$ \\
\hline & & 0.6011 & 5.6581 & 0.0371 & two months before: relative humidity \\
\hline & Juveniles & 0.8522 & 11.9341 & 0.0033 & two months before: relative humidity + max. temp. \\
\hline & & 0.8697 & 8.2778 & 0.0082 & $\begin{array}{l}\text { two months before: relative humidity }+ \text { max. temp. }+ \text { medium } \\
\text { temp. }\end{array}$ \\
\hline \multirow[t]{9}{*}{ Cerradão } & Total abundance & 0.8415 & 6.4704 & 0.0159 & current month: max. temp. + max. prec. in $24 \mathrm{~h}+$ total prec. \\
\hline & & 0.6440 & 7.0869 & 0.0228 & two months before: relative humidity \\
\hline & Richness & 0.7206 & 10.7996 & 0.0082 & current month: max. temp. \\
\hline & & 0.7789 & 4.1129 & 0.0486 & one month before: $\min$. temp. + max. temp. + relative humidity \\
\hline & & 0.6525 & 7.4171 & 0.0206 & two months before: min. temp. \\
\hline & Males & - & - & - & ns \\
\hline & Females & 0.6157 & 6.1047 & 0.0317 & current month: max. temp. \\
\hline & Juveniles & 0.8170 & 9.0367 & 0.0073 & two months before: relative humidity + total prec. \\
\hline & & 0.9270 & 7.3282 & 0.0164 & $\begin{array}{l}\text { two months before: relative humidity + total prec. + max. prec. } \\
\text { in } 24 \mathrm{~h}+\text { max. temp. + min. temp. }\end{array}$ \\
\hline
\end{tabular}

Significant $=p \leqslant 0.05$ ns $=$ no significant relationship. 


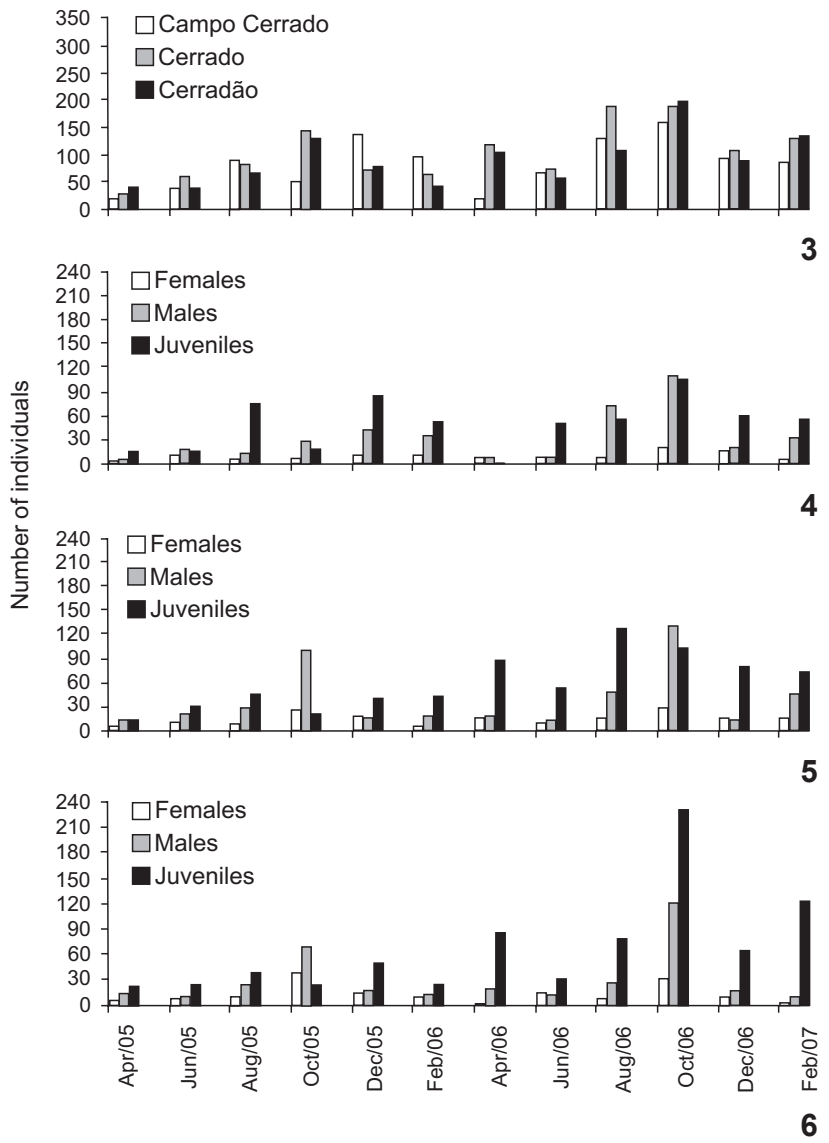

Figures 3-6. Total abundance of individuals sampled from the three Brazilian Savanna phytophysiognomies (3) and abundance of females, males and juveniles per area, (4) campo cerrado, (5) cerrado, and (6) cerradão.

in April in Campo Cerrado, and in June in the two other habitat types. April was the month with the lowest spider abundance of $(\mathrm{N}=265)$.

In the campo cerrado, $71 \%$ of the spiders were recorded during the wet season. Both dry and wet seasons had a higher proportion of juveniles than adults (58\% and 55\%, respectively). The same occurred in the Cerrado, where more individuals were registered during the wet season (70\%) but the largest proportion of juveniles was collected during dry season (64\%). In the Cerradão, the same pattern was found: more spiders were collected during the wet season (78\%) and a higher proportion of juveniles in the dry season (62\%).

The overall sex ratio of adult spiders showed a malebias (1.00 male: 0.27 female). When the eight most common families were analyzed separately, the result was a strong numerical dominance of Zodariidae males during the wet season in all areas ( $\mathrm{N}=117$ in Campo Cerrado, 174 in Cerrado and 153 in Cerradão), which influenced the overall sex ratio
(Figs 7-12). In general, the abundance of males was higher than that of females in both dry and wet seasons. Nevertheless, during the dry season, lycosids and hahniids (Campo Cerrado and Cerrado), and corinnids (Campo Cerrado) were more strongly represented by females than males. The same was true for the hahniids collected during wet season in Cerradão.

In the Campo Cerrado, sex ratio was 1.00 male: 0.20 females in the dry season and 1.00 male: 0.23 female in the wet season. In the Cerrado, sex ratio was 1.00 male: 0.35 female in dry season and 1.00 male: 0.34 female in wet season. In Cerradão, 1.00 male: 0.48 female were sampled in the dry season and 1.00 male: 0.28 female during wet season. No significant differences were found between the sex ratios in the three vegetation types $(\mathrm{F}=6.4040, \mathrm{p}=0.0578)$ nor between the seasons $(\mathrm{F}=0.7152, \mathrm{p}=0.5445)$.

In the Campo Cerrado, the most abundant families were Lycosidae $(\mathrm{N}=220,21 \%)$, Zodariidae $(\mathrm{N}=212,21 \%)$ and Linyphiidae $(\mathrm{N}=115,11 \%)$. The three most abundant species accounted for $22 \%$ of the total individuals. These were: Linyphiidae sp $2(\mathrm{~N}=82)$, with a higher abundance in February $(\mathrm{N}=19)$ and August $(\mathrm{N}=58)$; Leprolochus sp $(\mathrm{N}=80)$, found during most of the year, with higher abundance in the wet season from October to February $(\mathrm{N}=68)$, and Tenedos perfidus (Jocqué \& Baert, 2002) $(\mathrm{N}=58)$ sampled only in October $(\mathrm{N}=$ $56)$ and December $(\mathrm{N}=2)$.

The most abundant families in the Cerrado were Zodariidae $(\mathrm{N}=305,24 \%)$, Lycosidae $(\mathrm{N}=268,21 \%)$ and Theridiidae $(\mathrm{N}=156,12 \%)$. The three species with the highest number of individuals were $T$. perfidus $(\mathrm{N}=130)$, especially abundant in October $(\mathrm{N}=116)$, followed by Leprolochus sp. $(\mathrm{N}$ $=81)$ collected from August $(\mathrm{N}=1)$ to February $(\mathrm{N}=46)$, and Lycosinae sp. $1(\mathrm{~N}=59)$, sampled from August to December, with thehighest occurrence in October $(\mathrm{N}=55)$.

In the Cerradão, Lycosidae ( $\mathrm{N}=334,28 \%)$, Zodariidae ( $\mathrm{N}$ $=192,16 \%)$ and Corinnidae $(\mathrm{N}=160,13 \%)$ were the most abundant families. The three best represented species in our samples were $T$. perfidus $(\mathrm{N}=162)$, with the highest number of individuals collected in October $(\mathrm{N}=158)$; Lycosinae sp.1 $(\mathrm{N}=133)$ found only in October $(\mathrm{N}=129)$ and December $(\mathrm{N}=4)$ and Euryopis sp. $1(\mathrm{~N}=43)$, registered in almost every sampling period, but especially common from August to February $(\mathrm{N}=35)$.

Overall, the most abundant species in this study was $T$. perfidus, found in all phytophysiognomies. The abundance of this species followed a gradient of complexity from the Cerrado to the Cerradão ( $\mathrm{N}=58$ in the Campo Cerrado, 130 in the Cerrado and 162 in the Cerradão). It was more abundant during the wet season $(\mathrm{N}=347)$ than in the dry season (only two males and one female in the Cerrado). The distribution of this species over the year in each habitat type is described above. Males dominated the sample $(\mathrm{N}=312)$. Sex ratio varied from 1.00 male: 0.12 female during wet season to 1.00 male: 0.50 female during dry season. 

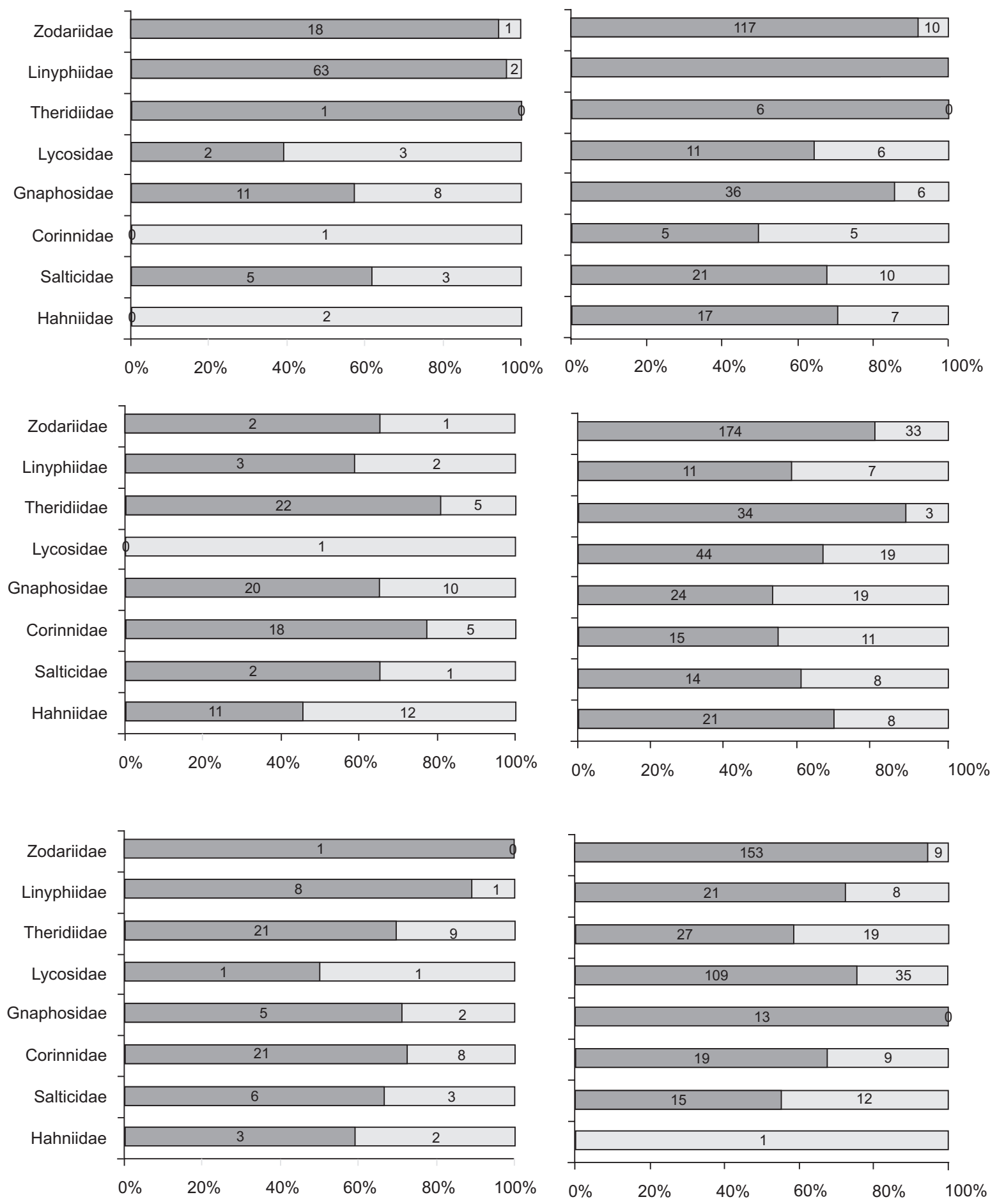

Figures 7-12. Proportion of males and females of the most common families of spiders found on the ground of the Panga Ecological Station, Minas Gerais, Brazil, in three distinct vegetal physiognomies: "campo cerrado" (7-8), "cerrado" (9-10) and "cerradão" (11-12) during dry $(7,9$, and 11$)$ and wet season $(8,10$, and 12$)$. 


\section{DISCUSSION}

Our results suggest that seasonal variation in abiotic factors influence the abundance, distribution and richness of spider species in the study area in the Brazilian Savanna. The impact of these factors on ground-dwelling spiders varied among habitat types. In general, delayed climatic conditions exerted more effects on spider populations than current conditions. This pattern was also observed in similar studies on spiders (Arango et al. 2000, Romero \& VASConcellos-Neto 2003). Severe dry seasons in some tropical regions, such as observed in the Brazilian Savanna, are likely the main factor reducing the abundance of arthropods, including spiders, in some periods of the year (JANZen \& SChoener 1968, JANZen 1973).

The quantity and quality of litter (as other factors) vary within phytophysiognomies, from almost nothing in the Campo Cerrado to a complex stratum in the Cerradão (OliveirAFilho \& Ratter 2002). Using experimental designs, Bultman \& Uетz (1982) were able to discriminate between the role of forest litter as a nutritional base for spider prey and its role of providing a spatially complex substrate. In that study, webbuilders were more abundant in structured, artificial litter, whereas hunting spiders preferred the prey-rich natural litter. Plant species in the tropical savannas have a great diversity of phenological strategies (Oliveira-Filho \& Ratter 2002). These differing strategies result in different patterns of abundance of herbivorous insects at any given period of the year, depending on resource availability (PINHEIRo et al. 2002), that will reflect on the abundance, diversity and seasonality of predators.

The higher proportion of adults trapped during the wet season and juveniles in the dry season indicate that many species have their period of reproduction during the wet season, particularly in October. During the reproductive season, males are probably more active searching for mates; consequently, they have a higher probability of being captured in the traps. In the first year of study, there was no marked peak in seasonal male abundance, probably because the heavy rains started late(November). During the second year, when precipitation was normal (starting in September), most spiders (predominantly males)were captured in October.

The overall sex ratio of adult spiders also changed over the year. Male dominance was expected since more active individuals are more likely to fall into the traps (Adis 2002). However, with the exception of four families, the male bias in the samples was greater in the wet season, suggesting that it can vary.

Even though Zodariidae and Lycosidae were the most frequent families in our samples for all three phytophysiognomies, the species within each habitat were different. The only exception was T. perfidus (Zodariidae), found in all three. The high abundance of this species is one of the most important findings of this study, because T. perfidus is endemic to the Brazilian Savanna. Previous information about this species in the literature is restricted to the original taxonomic description (see Jocqué \& BAERT 2002).

The present study found distinct compositions of spider species in the three habitat types sampled, with seasonal distribution and variations in sex ratios throughout the year. There were effects of climatic variables, notably humidity, but many other factors need to be investigated, including the diversity of hunting strategies and habitat selecion practiced by the animals, characteristics of the vegetation, prey availability and natural enemies. This is the first long term study investigating spider diversity and its relationship with seasonal variation and habitat distribution in the Brazilian tropical Savannas. The authors hope that it may stimulate other research projects in the future.

\section{ACKNOWLEDGMENTS}

We wish to thank the researchers of the Butantan Institute for the cooperation and assistance in the identification of the spiders, C.H. Mineo, R.G. de Oliveira and R.G.N. Ferreira for their tireless efforts in the field, and E. Tizo-Pedroso, O. Marçal Jr and H.M. Torezan-Silingardi for comments and suggestions on the manuscript. We also thank the Conselho Nacional de Desenvolvimento Científico e Tecnológico, Coordenação de Aperfeiçoamento de Pessoal de Nível Superior and Fundação de Amparo à Pesquisa de Minas Gerais, for financial support.

\section{LITERATURE CITED}

AdIs, J. 2002. Recommended sampling techniques, p. 555-576. In: J. AdIs (Ed). Amazonian Arachnida and Myriapoda. Sofia, Bulgaria, Pensoft Publishers, 590p.

Arango, A.M.; V. Rico-Gray \& V. Parra-Tabla. 2000. Population structure, seasonality, and habitat use by the green lynx spider Peucetia viridans (Oxyopidae) inhabiting Cnidoscolus aconitifolius (Euphorbiaceae). Journal of Arachnology 28: 185-194.

Ayres, M.; M. Ayres Júnior; D.L. Ayres \& A.A.Santos. 2007. BioEstat 5.0 - Aplicações estatísticas nas áreas das ciências biomédicas. Belém, Ong Mamiraua, 324p.

Bultman, T.L. \& G.W. UeTz. 1982. Abundance and community structure of forest floor spiders following litter manipulation. Oecologia 55: 34-41.

Gasnier, T.R.; M.P. Torres-Sanchez; C.S. Azevedo \& H. HöFer. 2002. Adult size of eight hunting spider species in central Amazonia: temporal variations and sexual dimorphisms. Journal of Arachnology 30: 146-154.

Gaston, H.J.; T.M. Blackburn; P.M. Hammond \& N.E. Stork. 1993. Relationships between abundance and body size: where do tourists fit? Ecological Entomology 18: 310-314.

Gottsberger, G. \& I. Silberbauer-Gottsberger. 2006. Life in the cerrado: A South American tropical seasonal ecosystem. Ulm, Reta Verlag, vol. 1, 277p.

Janzen, D.H. 1973. Sweep samples of tropical foliage insects: effects of seasons, vegetation types, elevation, time of the day, and insularity. Ecology 54: 687-702. 
Janzen, D.H. \& T.W. Schoener. 1968. Differences in insect abundance and diversity between wetter and drier sites during a tropical dry season. Ecology 49: 96-110.

JOCQUÉ, R. \& L. BAERT. 2002. A revision of the neotropical genera Tenedos O.P.-Cambridge and Ishania Chamberlin (Araneae, Zodariidae). Bulletin de L'institut Royal des Sciences Naturelles de Belgique, Entomologie 72: 67-173.

Modiba, M.A.; S.M. Dippenaar \& A.S. Dippenaar-Schoeman. 2005. A checklist of spiders from Sovenga Hill, an inselberg in the Savanna Biome, Limpopo Province, South Africa (Arachnida: Araneae). Koedoe 48: 109-115.

Oliveira, P.S. \& R.J. Marquis. 2002. The cerrados of Brazil: ecology and natural history of a neotropical savanna. New York, Columbia University Press, 424p.

Pinheiro, F.; I.R. Diniz; D. Coelho \& M.P.S. Bandeira. 2002. Seasonal pattern of insect abundance in the Brazilian cerrado. Austral Ecology 27: 132-136.

RINALDI, I.M.P. \& L.C. ForTi. 1996. Strategies for habitat use among species of hunting spiders (Araneomorphae, Dionycha) in natural and artificial biotopes from southeastern Brazil. Acta Biologica Paranaense 25: 115-139.

Romero, G.Q. \& J. Vasconcellos-Neto. 2003. Natural history of Misumenops argenteus Rinaldi (1988) (Araneae, Thomisidae): seasonality and diet on Trichogoniopsis adenantha (Asteraceae). Journal of Arachnology 31: 297-304.
Rosenzweig, M.L. 1995. Species diversity in space and time. Cambridge, Cambridge University Press, 460p.

Russel-Smith, A. 2002. A comparison of the diversity and composition of ground-active spiders in Mkomazi Game Reserve, Tanzania and Etosha National Park, Namibia. Journal of Arachnology 30: 383-388.

Schiavini, I. \& G.M.Araujo. 1992. Considerações sobre a vegetação da Reserva Ecológica do Panga (Uberlândia). Sociedade e Natureza 1: 61-66.

Uetz, G.W. 1992. Foraging strategies of spiders. Trends in Ecology and Evolution 7: 155-159.

Whitmore, C; R. Slotow; T.E. Crouch \& A.S. Dippenaar-Schoeman. 2002. Diversity of spiders (Araneae) in a savanna reserve, northern province, South Africa. Journal of Arachnology 30: 344-356.

Wise, D.H. 1993. Spiders in ecological webs. Cambridge, Cambridge University Press, 328p.

Wolda, H. 1988. Insect seasonality: why? Annual Review of Ecology and Systematics 19: 1-18.

Submitted: 14.IX.2009; Accepted: 24.III.2010. Editorial responsibility: Walter P. Boeger

Appendix 1. Number of families and species of ground-dwelling spiders of three distinct phytophysiognomies of a Brazilian Savanna during dry (May-September) and wet seasons (October-April).

\begin{tabular}{|c|c|c|c|c|c|c|c|c|c|c|c|c|c|c|c|c|}
\hline \multirow{3}{*}{ Families/species } & \multicolumn{4}{|c|}{ Campo cerrado } & \multicolumn{4}{|c|}{ Cerrado } & \multicolumn{4}{|c|}{ Cerradão } & \multicolumn{4}{|c|}{ Total } \\
\hline & \multicolumn{2}{|c|}{ Dry season } & \multicolumn{2}{|c|}{ Wet season } & \multicolumn{2}{|c|}{ Dry season } & \multicolumn{2}{|c|}{ Wet season } & \multicolumn{2}{|c|}{ Dry season } & \multicolumn{2}{|c|}{ Wet season } & \multicolumn{2}{|c|}{ Dry season } & \multicolumn{2}{|c|}{ Wet season } \\
\hline & A & $J$ & A & $J$ & A & $J$ & A & 1 & A & $J$ & A & $J$ & A & J & A & 1 \\
\hline Anyphaenidae & 0 & 0 & 0 & 0 & 0 & 1 & 1 & 0 & 0 & 0 & 3 & 1 & 0 & 1 & 4 & 1 \\
\hline Aysha sp. & 0 & & 0 & & 0 & & 1 & & 0 & & 3 & & 0 & & 4 & \\
\hline Barychelidae & 0 & 0 & 0 & 9 & 0 & 1 & 0 & 2 & 0 & 0 & 0 & 6 & 0 & 1 & 0 & 17 \\
\hline Caponiidae & 0 & 6 & 1 & 4 & 2 & 7 & 4 & 17 & 1 & 6 & 7 & 19 & 3 & 19 & 12 & 40 \\
\hline Caponina notabilis (Mello-Leitão, 1939) & 0 & & 1 & & 1 & & 1 & & 0 & & 1 & & 1 & & 3 & \\
\hline Nops sp. & 0 & & 0 & & 1 & & 3 & & 1 & & 6 & & 2 & & 9 & \\
\hline Clubionidae & 0 & 0 & 0 & 0 & 0 & 0 & 1 & 0 & 0 & 0 & 0 & 0 & 0 & 0 & 1 & 0 \\
\hline Elaver brevipes (Keyserling, 1891) & 0 & & 0 & & 0 & & 1 & & 0 & & 0 & & 0 & & 1 & \\
\hline Corinnidae & 1 & 5 & 10 & 5 & 23 & 7 & 27 & 29 & 29 & 7 & 28 & 96 & 53 & 19 & 65 & 130 \\
\hline Abapeba rioclaro Bonaldo, 2000 & 0 & & 0 & & 0 & & 1 & & 0 & & 0 & & 0 & & 1 & \\
\hline Attacobius sp. & 0 & & 0 & & 0 & & 0 & & 0 & & 3 & & 0 & & 3 & \\
\hline Castianeira sp. 1 & 0 & & 1 & & 2 & & 5 & & 0 & & 3 & & 2 & & 9 & \\
\hline Castianeira sp. 2 & 0 & & 1 & & 11 & & 8 & & 12 & & 14 & & 23 & & 23 & \\
\hline Castianeira sp. 3 & 0 & & 0 & & 1 & & 3 & & 9 & & 3 & & 10 & & 6 & \\
\hline Falconina sp. & 1 & & 2 & & 1 & & 6 & & 0 & & 1 & & 2 & & 9 & \\
\hline Mazax sp. & 0 & & 0 & & 0 & & 3 & & 1 & & 1 & & 1 & & 4 & \\
\hline Orthobula sp. & 0 & & 5 & & 8 & & 1 & & 7 & & 3 & & 15 & & 9 & \\
\hline
\end{tabular}


Appendix 1. Continued.

\begin{tabular}{|c|c|c|c|c|c|c|c|c|c|c|c|c|c|c|c|c|}
\hline \multirow{3}{*}{ Families/species } & \multicolumn{4}{|c|}{ Campo cerrado } & \multicolumn{4}{|c|}{ Cerrado } & \multicolumn{4}{|c|}{ Cerradão } & \multicolumn{4}{|c|}{ Total } \\
\hline & \multicolumn{2}{|c|}{ Dry season } & \multicolumn{2}{|c|}{ Wet season } & \multicolumn{2}{|c|}{ Dry season } & \multicolumn{2}{|c|}{ Wet season } & \multicolumn{2}{|c|}{ Dry season } & \multicolumn{2}{|c|}{ Wet season } & \multicolumn{2}{|c|}{ Dry season } & \multicolumn{2}{|c|}{ Wet season } \\
\hline & A & 1 & $\mathrm{~A}$ & $\mathrm{~J}$ & $\mathrm{~A}$ & 1 & $\mathrm{~A}$ & J & $\mathrm{A}$ & J & $\mathrm{A}$ & J & $\mathrm{A}$ & 1 & $\mathrm{~A}$ & J \\
\hline Trachelinae sp. & 0 & & 1 & & 0 & & 0 & & 0 & & 0 & & 0 & & 1 & \\
\hline Ctenidae & 0 & 9 & 0 & 5 & 0 & 8 & 2 & 30 & 4 & 3 & 0 & 25 & 4 & 20 & 3 & 60 \\
\hline Parabatinga taeniata (Keyserling, 1891) & 0 & & 0 & & 0 & & 1 & & 1 & & 0 & & 1 & & 1 & \\
\hline Isoctenus sp. 1 & 0 & & 0 & & 0 & & 0 & & 2 & & 0 & & 2 & & 0 & \\
\hline Isoctenus sp. 2 & 0 & & 0 & & 0 & & 0 & & 1 & & 0 & & 1 & & 0 & \\
\hline Phoneutria nigriventer (Keyserling, 1891) & 0 & & 0 & & 0 & & 2 & & 0 & & 0 & & 0 & & 2 & \\
\hline Dictynidae & 1 & 0 & 0 & 0 & 0 & 0 & 0 & 0 & 0 & 0 & 0 & 0 & 1 & 0 & 0 & 0 \\
\hline Dictyna sp. 1 & 1 & & 0 & & 0 & & 0 & & 0 & & 0 & & 1 & & 0 & \\
\hline Dipluridae & 0 & 0 & 0 & 0 & 0 & 0 & 0 & 0 & 0 & 0 & 0 & 1 & 0 & 0 & 0 & 1 \\
\hline Gnaphosidae & 19 & 13 & 42 & 33 & 29 & 16 & 43 & 38 & 7 & 7 & 13 & 29 & 55 & 36 & 98 & 100 \\
\hline Apopyllus sp. 1 & 4 & & 6 & & 6 & & 21 & & 0 & & 10 & & 10 & & 37 & \\
\hline Apopyllus silvestrii (Simon, 1905) & 14 & & 33 & & 4 & & 21 & & 1 & & 0 & & 19 & & 54 & \\
\hline Camillina cordoba Platnick \& Murphy, 1987 & 0 & & 1 & & 17 & & 1 & & 4 & & 2 & & 21 & & 4 & \\
\hline Camillina sp. 1 & 0 & & 2 & & 1 & & 0 & & 2 & & 0 & & 3 & & 2 & \\
\hline Cesonia sp. & 1 & & 0 & & 0 & & 0 & & 0 & & 0 & & 1 & & 0 & \\
\hline Vectius niger (Simon, 1880) & 0 & & 0 & & 1 & & 0 & & 0 & & 1 & & 1 & & 1 & \\
\hline Hahniidae & 2 & 0 & 24 & 5 & 23 & 5 & 24 & 4 & 3 & 0 & 3 & 0 & 28 & 5 & 51 & 9 \\
\hline Hahniidae sp. 1 & 2 & & 24 & & 23 & & 21 & & 3 & & 3 & & 28 & & 48 & \\
\hline Hahniidae sp. 2 & 0 & & 0 & & 0 & & 3 & & 0 & & 0 & & 0 & & 3 & \\
\hline Hersiliidae & 0 & 0 & 1 & 0 & 0 & 0 & 1 & 1 & 0 & 0 & 0 & 0 & 0 & 0 & 2 & 1 \\
\hline Iviraiva argentina (Mello-Leitão, 1942) & 0 & & 1 & & 0 & & 1 & & 0 & & 0 & & 0 & & 2 & \\
\hline Linyphiidae & 65 & 3 & 39 & 8 & 5 & 25 & 18 & 17 & 9 & 16 & 29 & 25 & 79 & 44 & 86 & 50 \\
\hline Linyphiidae sp. 1 & 4 & & 13 & & 4 & & 13 & & 1 & & 13 & & 9 & & 39 & \\
\hline Linyphiidae sp. 2 & 60 & & 22 & & 1 & & 3 & & 2 & & 4 & & 63 & & 29 & \\
\hline Linyphiidae sp. 3 & 0 & & 0 & & 0 & & 1 & & 4 & & 0 & & 4 & & 1 & \\
\hline Linyphiidae sp .4 & 0 & & 0 & & 0 & & 0 & & 1 & & 0 & & 1 & & 0 & \\
\hline Linyphiidae sp .5 & 1 & & 0 & & 0 & & 0 & & 0 & & 0 & & 1 & & 0 & \\
\hline Linyphiidae sp. 6 & 0 & & 0 & & 0 & & 1 & & 0 & & 10 & & 0 & & 11 & \\
\hline Linyphiidae sp. 7 & 0 & & 3 & & 0 & & 0 & & 1 & & 0 & & 1 & & 3 & \\
\hline Linyphiidae sp. 8 & 0 & & 1 & & 0 & & 0 & & 0 & & 1 & & 0 & & 2 & \\
\hline Linyphiidae sp. 9 & 0 & & 0 & & 0 & & 0 & & 0 & & 1 & & 0 & & 1 & \\
\hline Lycosidae & 5 & 71 & 17 & 127 & 1 & 80 & 63 & 124 & 2 & 89 & 144 & 99 & 8 & 240 & 224 & 350 \\
\hline Aglaoctenus lagotis (Holmberg 1876) & 0 & & 1 & & 0 & & 0 & & 0 & & 0 & & 0 & & 1 & \\
\hline Artcosa sp. & 0 & & 0 & & 0 & & 0 & & 1 & & 0 & & 1 & & 0 & \\
\hline Hogna gumia (Petrunkevitch 1911) & 0 & & 0 & & 0 & & 0 & & 0 & & 3 & & 0 & & 3 & \\
\hline Hogna pardalina (Bertkau, 1880) & 0 & & 4 & & 0 & & 0 & & 0 & & 3 & & 0 & & 7 & \\
\hline Hogna sp.1 & 0 & & 1 & & 0 & & 0 & & 0 & & 0 & & 0 & & 1 & \\
\hline Lycosa inornata (Blackwall, 1862) & 0 & & 2 & & 0 & & 0 & & 0 & & 0 & & 0 & & 2 & \\
\hline Lycosa tarantuloides (Perty, 1833) & 3 & & 2 & & 0 & & 0 & & 0 & & 0 & & 3 & & 2 & \\
\hline Lycosa sp. 1 & 1 & & 0 & & 0 & & 0 & & 0 & & 0 & & 1 & & 0 & \\
\hline Lycosa sp. 2 & 1 & & 0 & & 0 & & 1 & & 0 & & 0 & & 1 & & 1 & \\
\hline Molitorosa molitor (Bertkau, 1880) & 0 & & 0 & & 0 & & 1 & & 0 & & 0 & & 0 & & 1 & \\
\hline
\end{tabular}


Appendix 1. Continued.

\begin{tabular}{|c|c|c|c|c|c|c|c|c|c|c|c|c|c|c|c|c|}
\hline \multirow{3}{*}{ Families/species } & \multicolumn{4}{|c|}{ Campo cerrado } & \multicolumn{4}{|c|}{ Cerrado } & \multicolumn{4}{|c|}{ Cerradão } & \multicolumn{4}{|c|}{ Total } \\
\hline & \multicolumn{2}{|c|}{ Dry season } & \multicolumn{2}{|c|}{ Wet season } & \multicolumn{2}{|c|}{ Dry season } & \multicolumn{2}{|c|}{ Wet season } & \multicolumn{2}{|c|}{ Dry season } & \multicolumn{2}{|c|}{ Wet season } & \multicolumn{2}{|c|}{ Dry season } & \multicolumn{2}{|c|}{ Wet season } \\
\hline & A & J & A & J & A & J & A & J & A & J & A & J & A & J & A & J \\
\hline Pavocosa sp. & 0 & & 3 & & 0 & & 0 & & 0 & & 0 & & 0 & & 3 & \\
\hline Trochosa sp. & 0 & & 0 & & 0 & & 0 & & 0 & & 4 & & 0 & & 4 & \\
\hline Lycosinae sp. & 0 & & 0 & & 1 & & 58 & & 0 & & 133 & & 1 & & 191 & \\
\hline Lycosidae sp. & 0 & & 4 & & 0 & & 3 & & 1 & & 1 & & 1 & & 8 & \\
\hline Miturgidae & 0 & 10 & 3 & 22 & 0 & 2 & 2 & 6 & 0 & 0 & 0 & 0 & 0 & 12 & 5 & 28 \\
\hline Teminius sp. & 0 & & 3 & & 0 & & 2 & & 0 & & 0 & & 0 & & 5 & \\
\hline Ochyroceratidae & 0 & 0 & 0 & 0 & 0 & 0 & 0 & 0 & 1 & 0 & 0 & 2 & 1 & 0 & 0 & 2 \\
\hline Speocera sp. & 0 & & 0 & & 0 & & 0 & & 1 & & 0 & & 1 & & 0 & \\
\hline Oonopidae & 0 & 11 & 0 & 5 & 0 & 4 & 1 & 24 & 1 & 2 & 6 & 37 & 1 & 17 & 7 & 66 \\
\hline Neoxyphinus sp. & 0 & & 0 & & 0 & & 0 & & 0 & & 4 & & 0 & & 4 & \\
\hline Oonops sp. & 0 & & 0 & & 0 & & 1 & & 0 & & 0 & & 0 & & 1 & \\
\hline Triaeris stenaspis Simon, 1891 & 0 & & 0 & & 0 & & 0 & & 0 & & 2 & & 0 & & 2 & \\
\hline Gamasomorphiinae sp. & 0 & & 0 & & 0 & & 0 & & 1 & & 0 & & 1 & & 0 & \\
\hline Oxyopidae & 0 & 12 & 13 & 47 & 0 & 3 & 3 & 1 & 0 & 0 & 1 & 0 & 0 & 15 & 17 & 48 \\
\hline Oxyopes salticus Hentz, 1845 & 0 & & 13 & & 0 & & 3 & & 0 & & 1 & & 0 & & 17 & \\
\hline Palpimanidae & 0 & 0 & 1 & 0 & 0 & 0 & 0 & 0 & 0 & 0 & 0 & 0 & 0 & 0 & 1 & 0 \\
\hline Otiothops recurvus Platnick, 1976 & 0 & & 1 & & 0 & & 0 & & 0 & & 0 & & 0 & & 1 & \\
\hline Philodromidae & 3 & 0 & 0 & 1 & 0 & 1 & 2 & 0 & 0 & 0 & 1 & 3 & 3 & 1 & 3 & 3 \\
\hline Berlandiella sp. 1 & 0 & & 0 & & 0 & & 2 & & 0 & & 1 & & 0 & & 3 & \\
\hline Berlandiella sp. 2 & 1 & & 0 & & 0 & & 0 & & 0 & & 0 & & 1 & & 0 & \\
\hline Tibellus sp. & 2 & & 0 & & 0 & & 0 & & 0 & & 0 & & 2 & & 0 & \\
\hline Pholcidae & 1 & 2 & 8 & 1 & 5 & 3 & 9 & 6 & 2 & 1 & 6 & 2 & 8 & 6 & 23 & 9 \\
\hline Ibotyporanga naideae (M-Leitão, 1944) & 1 & & 6 & & 5 & & 8 & & 2 & & 6 & & 8 & & 20 & \\
\hline Mesabolivar sp. & 0 & & 2 & & 0 & & 1 & & 0 & & 0 & & 0 & & 3 & \\
\hline Prodidomidae & 0 & 0 & 0 & 0 & 0 & 0 & 1 & 0 & 0 & 0 & 0 & 0 & 0 & 0 & 1 & 0 \\
\hline Lygromma sp. & 0 & & 0 & & 0 & & 1 & & 0 & & 0 & & 0 & & 1 & \\
\hline Salticidae & 8 & 14 & 30 & 37 & 3 & 9 & 22 & 28 & 9 & 6 & 27 & 40 & 20 & 29 & 79 & 105 \\
\hline Aillutticus sp. & 0 & & 5 & & 0 & & 3 & & 0 & & 0 & & 0 & & 8 & \\
\hline Amatorculus sp. & 1 & & 0 & & 0 & & 1 & & 0 & & 0 & & 1 & & 1 & \\
\hline Amphidraus sp. 1 & 1 & & 1 & & 0 & & 9 & & 3 & & 12 & & 4 & & 22 & \\
\hline Amphidraus sp. 2 & 0 & & 0 & & 0 & & 0 & & 0 & & 8 & & 0 & & 8 & \\
\hline Aphirape sp. & 0 & & 3 & & 0 & & 0 & & 0 & & 0 & & 0 & & 3 & \\
\hline Breda apicalis Simon, 1901 & 0 & & 0 & & 0 & & 0 & & 0 & & 1 & & 0 & & 1 & \\
\hline Breda bistriata (C.L. Koch, 1846) & 0 & & 0 & & 0 & & 0 & & 0 & & 1 & & 0 & & 1 & \\
\hline Breda sp. 1 & 0 & & 0 & & 0 & & 1 & & 0 & & 0 & & 0 & & 1 & \\
\hline Chira simoni Galiano, 1961 & 0 & & 0 & & 1 & & 0 & & 0 & & 0 & & 1 & & 0 & \\
\hline Chira sp. & 0 & & 0 & & 0 & & 0 & & 0 & & 1 & & 0 & & 1 & \\
\hline Corythalia sp. & 0 & & 6 & & 0 & & 0 & & 1 & & 0 & & 1 & & 6 & \\
\hline Freya sp. & 0 & & 1 & & 1 & & 0 & & 2 & & 0 & & 3 & & 1 & \\
\hline Hisukattus sp. & 0 & & 1 & & 0 & & 0 & & 0 & & 1 & & 0 & & 2 & \\
\hline Myrmarachne sp. & 0 & & 0 & & 0 & & 0 & & 0 & & 1 & & 0 & & 1 & \\
\hline Neonella sp. & 0 & & 1 & & 0 & & 0 & & 0 & & 0 & & 0 & & 1 & \\
\hline Semiopyla sp. 1 & 0 & & 3 & & 0 & & 0 & & 0 & & 0 & & 0 & & 3 & \\
\hline
\end{tabular}


Appendix 1. Continued.

\begin{tabular}{|c|c|c|c|c|c|c|c|c|c|c|c|c|c|c|c|c|}
\hline \multirow{3}{*}{ Families/species } & \multicolumn{4}{|c|}{ Campo cerrado } & \multicolumn{4}{|c|}{ Cerrado } & \multicolumn{4}{|c|}{ Cerradão } & \multicolumn{4}{|c|}{ Total } \\
\hline & \multicolumn{2}{|c|}{ Dry season } & \multicolumn{2}{|c|}{ Wet season } & \multicolumn{2}{|c|}{ Dry season } & \multicolumn{2}{|c|}{ Wet season } & \multicolumn{2}{|c|}{ Dry season } & \multicolumn{2}{|c|}{ Wet season } & \multicolumn{2}{|c|}{ Dry season } & \multicolumn{2}{|c|}{ Wet season } \\
\hline & $\mathrm{A}$ & $J$ & $\mathrm{~A}$ & $J$ & $\mathrm{~A}$ & $J$ & $\mathrm{~A}$ & 1 & $\mathrm{~A}$ & J & A & $J$ & $\mathrm{~A}$ & J & $\mathrm{A}$ & $J$ \\
\hline Semiopyla sp. 2 & 0 & & 0 & & 0 & & 0 & & 3 & & 0 & & 3 & & 0 & \\
\hline Sitticus sp. & 0 & & 3 & & 0 & & 0 & & 0 & & 0 & & 0 & & 3 & \\
\hline Sumampattus sp. & 0 & & 2 & & 0 & & 2 & & 0 & & 0 & & 0 & & 4 & \\
\hline Tamybelus sp. & 0 & & 0 & & 0 & & 4 & & 0 & & 2 & & 0 & & 6 & \\
\hline Thiodina sp. & 0 & & 0 & & 0 & & 1 & & 0 & & 0 & & 0 & & 1 & \\
\hline Freyinae sp. 1 & 5 & & 0 & & 0 & & 0 & & 0 & & 0 & & 5 & & 0 & \\
\hline Freyinae sp. 2 & 0 & & 0 & & 1 & & 0 & & 0 & & 0 & & 1 & & 0 & \\
\hline Freyinae sp. 3 & 0 & & 2 & & 0 & & 0 & & 0 & & 0 & & 0 & & 2 & \\
\hline Freyinae sp. 4 & 0 & & 1 & & 0 & & 1 & & 0 & & 0 & & 0 & & 2 & \\
\hline Sitticinae sp. & 1 & & 1 & & 0 & & 0 & & 0 & & 0 & & 1 & & 1 & \\
\hline Selenopidae & 0 & 0 & 0 & 0 & 1 & 0 & 0 & 0 & 0 & 0 & 0 & 0 & 1 & 0 & 0 & 0 \\
\hline Selenops sp. & 0 & & 0 & & 1 & & 0 & & 0 & & 0 & & 1 & & 0 & \\
\hline Sparassidae & 0 & 0 & 0 & 0 & 0 & 2 & 0 & 1 & 2 & 1 & 0 & 0 & 2 & 3 & 0 & 1 \\
\hline Olios sp. & 0 & & 0 & & 0 & & 0 & & 2 & & 0 & & 2 & & 0 & \\
\hline Theraphosidae & 0 & 0 & 0 & 0 & 0 & 0 & 0 & 2 & 0 & 0 & 0 & 0 & 0 & 0 & 0 & 2 \\
\hline Theridiidae & 1 & 3 & 7 & 33 & 46 & 42 & 18 & 50 & 30 & 3 & 46 & 69 & 77 & 48 & 71 & 152 \\
\hline Coleosoma floridanum Banks, 1900 & 1 & & 0 & & 19 & & 2 & & 14 & & 3 & & 34 & & 5 & \\
\hline Dipoena sp. & 0 & & 0 & & 0 & & 0 & & 5 & & 5 & & 5 & & 5 & \\
\hline Euryopis sp. 1 & 0 & & 3 & & 27 & & 15 & & 11 & & 32 & & 38 & & 50 & \\
\hline Euryopis sp. 2 & 0 & & 2 & & 0 & & 0 & & 0 & & 0 & & 0 & & 2 & \\
\hline Steatoda sp. & 0 & & 1 & & 0 & & 0 & & 0 & & 0 & & 0 & & 1 & \\
\hline Thymoites sp. & 0 & & 0 & & 0 & & 1 & & 0 & & 4 & & 0 & & 5 & \\
\hline Theridiidae sp. 1 & 0 & & 1 & & 0 & & 0 & & 0 & & 0 & & 0 & & 1 & \\
\hline Theridiidae sp. 2 & 0 & & 0 & & 0 & & 0 & & 0 & & 2 & & 0 & & 2 & \\
\hline Thomisidae & 0 & 2 & 2 & 2 & 0 & 1 & 3 & 4 & 0 & 2 & 1 & 6 & 0 & 5 & 6 & 12 \\
\hline Synstrophius sp. & 0 & & 1 & & 0 & & 2 & & 0 & & 0 & & 0 & & 3 & \\
\hline Tmarus sp. 1 & 0 & & 0 & & 0 & & 0 & & 0 & & 1 & & 0 & & 1 & \\
\hline Tmarus sp. 2 & 0 & & 0 & & 0 & & 1 & & 0 & & 0 & & 0 & & 1 & \\
\hline Tmarus sp. 3 & 0 & & 1 & & 0 & & 0 & & 0 & & 0 & & 0 & & 1 & \\
\hline Titanoecidae & 0 & 1 & 3 & 0 & 0 & 0 & 1 & 0 & 0 & 1 & 1 & 0 & 0 & 2 & 5 & 0 \\
\hline Goeldia luteipes (Keyserling, 1891) & 0 & & 2 & & 0 & & 0 & & 0 & & 0 & & 0 & & 2 & \\
\hline Goeldia sp. & 0 & & 1 & & 0 & & 1 & & 0 & & 1 & & 0 & & 3 & \\
\hline Trechaleidae & 0 & 0 & 0 & 0 & 0 & 0 & 1 & 0 & 0 & 0 & 0 & 0 & 0 & 0 & 1 & 0 \\
\hline Neoctenus comosus Simon, 1897 & 0 & & 0 & & 0 & & 1 & & 0 & & 0 & & 0 & & 1 & \\
\hline Trochanteridae & 0 & 0 & 0 & 0 & 0 & 0 & 0 & 0 & 0 & 0 & 1 & 0 & 0 & 0 & 1 & 0 \\
\hline Trochanteria gomezi Canals, 1933 & 0 & & 0 & & 0 & & 0 & & 0 & & 1 & & 0 & & 1 & \\
\hline Zodariidae & 19 & 9 & 127 & 57 & 4 & 32 & 207 & 62 & 1 & 18 & 162 & 11 & 24 & 59 & 496 & 130 \\
\hline Cybaeodamus sp. & 8 & & 0 & & 0 & & 0 & & 0 & & 0 & & 8 & & 0 & \\
\hline Leprolochus sp. & 11 & & 69 & & 1 & & 80 & & 1 & & 0 & & 13 & & 149 & \\
\hline Tenedos perfidus Jocqué \& Baert, 2002 & 0 & & 58 & & 3 & & 127 & & 0 & & 162 & & 3 & & 347 & \\
\hline \multirow[t]{3}{*}{ Total } & 125 & 171 & 328 & 401 & 142 & 249 & 454 & 446 & 101 & 163 & 479 & 470 & 368 & 583 & 1261 & 1317 \\
\hline & 296 & & 729 & & 391 & & 900 & & 264 & & 949 & & 951 & & 2578 & \\
\hline & 1025 & & & & 1291 & & & & 1213 & & & & 3529 & & & \\
\hline
\end{tabular}

ZOOLOGIA 27 (3): 353-362, June, 2010 